Jnl of Ecclesiastical History, Vol. 72, No. 3, July 202 I. $\quad$ (C) The Author(s), 2020. Published by Cambridge University Press. This is an Open Access article, distributed under the terms of the Creative Commons Attribution licence (http:/ / creativecommons.org/licenses/by/4.o/), which permits unrestricted re-use, distribution, and reproduction in any medium, provided the original work is properly cited. doi:10.1017/SoO22046920001499

\title{
Charity as Social Justice: Antonio Rosmini and the Great Irish Famine
}

\author{
by FRANCESCO ZAVATTI \\ Roma Tre University/Södertörn University, Sweden \\ E-mail: francesco.zavatti@sh.se
}

The article sheds light on the significant fundraising and relief activities for Ireland during the Great Famine (I 845-50) initiated in I 847 by the Italian philosopher and cleric Antonio Rosmini and his network in Savoy-Piedmont, Lombardy-Venetia and England. By analysing Rosmini's philosophical and political writings, the article demonstrates that Rosmini considered aid in times of crisis as an act of social justice for which individuals have to take responsibility. By analysing documents from the Italian and Irish archives, the article gives an account of the fundraising effort's practices of networking, appealing, almsgiving and delivery.

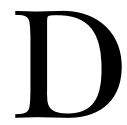
uring the Great Irish Famine $\left(1845^{-5}\right)$, various public and civil society organisations set up fundraising campaigns for the starving Irish people. Recent scholarship has interpreted this global activism as the kindness of foreigners providing succour during a humanitarian crisis that the British government was inadequately remedying. ${ }^{1}$ This interpretation assumes that foreign relief was liberally provided and had no specific agenda. However, the donors must have had at least a vague idea of why the Irish people, among all those going hungry, deserved help: the famine $\mathrm{ASIC}=$ Archive of the Institute of Charity, Stresa: AG = Archivo Generalizio; DDA = Dublin Diocesan Archive, Dublin; PIC = Pontifical Irish College, Rome: NC = New Collection

This article was financed by the research grant 'L'economia morale della società civile globale', co-financed by and based at the Department of Political Sciences, Roma Tre University, under the supervision of Professor Alberto Basciani, and the Swedish National Research Council (Vetenskapsrådet, grant number 2012-0o614) through the project 'The Moral Economy of the Global Civil Society', directed by Professor Norbert Götz of Södertörn University. The author wishes to thank the two anonymous reviewers for this JouRnAL whose comments and suggestions helped to improve and clarify an earlier version of this manuscript.

${ }^{1}$ C. Kinealy, Charity and the Great Hunger in Ireland: the kindness of strangers, London 2013 . 
hit other nearby areas within the United Kingdom of Great Britain and Ireland, as well as the rest of Europe. ${ }^{2}$ At that time, several European newspapers wrote about the oppressed nationalities of distant empires to conspiratorially wink at their readers and remind them of their own national oppression. ${ }^{3}$ In some cases, cross-border charity sought to demonstrate that a foreign power could not provide for its own people. 4

According to a view widely held among Catholics, and European public opinion at large, the Great Irish Famine resulted from the inactivity of the British government, which had let the Irish people starve without providing sufficient help. 5 Religious organisations raised funds sometimes in competition with other organisations in order to maximise support: in Rome, once the Catholic prelates started to raise funds for the Irish in early 1847 , their appeals to Pope Pius Ix did not fail to mention that the Anglican clergy had already begun to collect money. ${ }^{6}$

Focusing on fundraising provides an opportunity to investigate the moral economy of fundraisers and donors, and their way of injecting altruistic meaning into economic transactions, 7 and to understand what creates the desire to give charity and to organise complex alms collections for a specific group of starving people. Among the private relief efforts across the globe for Ireland, the Catholic priest and philosopher Antonio Rosmini organised in 1847 a wide-ranging alms collection for Irish Catholic paupers, fundraising in Savoy-Piedmont and the Kingdom of Lombardy-Venetia. Rosmini's order, the Institute of Charity, had expanded in 1835 from Savoy-Piedmont to England. With a limited number of Italian, English and Irish supporters, Rosmini offered much-needed help. This article focuses on the humanitarian actions of Rosmini and his network of Catholic helpers, its practices and motivation. Previous research is vague regarding how the Institute's fundraising was organised. ${ }^{8}$ By

${ }^{2}$ C. Ó Gráda, R. Paping and E. Vanhaute (eds), When the potato failed: causes and effects of the 'last' European subsistence crisis, I845-I85o, Turnhout 2007.

3 S. Mitu, National identity of the Romanians in Transylvania, Budapest 2001; L. Ferris, 'Irish views on old Austria and Austrian views on the Irish question, 1848-1918', unpubl. PhD diss. Wien 2008.

4 A. G. Newby and T. Myllyntaus, "The terrible visitation": famine in Finland and Ireland, 1845 to 1868: towards an agenda for comparative Irish-Finnish famine studies', in D. Curran, L. Luciuk and Andrew G. Newby (eds), Famines in European economic history: the last great European famines reconsidered, Abingdon $2015,148$.

5 E. F. Biagini, Storia dell'Irlanda dal I 845 a oggi, Bologna 2014, 19-42.

${ }^{6}$ Paul Cullen to Giacomo Fransoni, early January 1847 , Cullen papers, PIC, NC, $3 / 1 / 7$.

7 Norbert Götz, “"Moral economy”: its conceptual history and analytical prospects', Journal of Global Ethics xi (2015), 147-62 at p. $15^{8 .}$

${ }^{8}$ G. B. Pagani, La vita di Luigi Gentili, Rome 1904, 377 n. 3; D. Gwynn, Father Luigi Gentili and his missions (I $80 \mathrm{I}_{-1} 8_{4} \mathrm{I}$ ), Dublin 1951, $213^{-14}$; cf. Alessandro D'Angennes to Antonio Rosmini, 16 Jan. 1847 , ASIC, Aı, XXII, 1847, fo. 20. 
contextualising Rosmini's thought and activities, and by examining his philosophical writings and personal correspondence, this article shows why he decided to help the Irish people, to what extent and by which means.

\section{Rosmini in his times (I 797-I847)}

The fundraising for Ireland organised by Rosmini was a minor activity within the daily occupations of the Roveretano and his fellow donors during 1847 . However, the motivation that inspired this transnational moral economy and the practices by which it was advertised and implemented took its origins from a precise, yet intricate, political and cultural context. The elite of Savoy-Piedmont and Lombardy-Venetia who took part in the fundraising enterprise were part of a Catholic revival. Entitlement was one of the focal points of the new Catholic philosophies and doctrines that animated public debates and engendered active societal engagement.

The ideas and practices of this Catholic revival, begun as a reaction to the Napoleonic order, were fostered during the Restoration by discontented aristocrats and clergy. The absolute monarchs of the Restoration justified their legitimacy by propagandising the alliance of Throne and Altar and by implementing paternalistic policies of state-led charity. However, the Restoration regimes also dismantled the privileges of the aristocracy and the clergy, and their involvement in public life. This political setting engendered a discourse on entitlement to rights and privileges, on despotism and tyranny and on just forms of government. In a situation of rapid social mobility, compromise with and profit from loyalty to the throne were necessary. The social and cultural cohesion of aristocrats and clergy was a response to instability in a search for a viable programme of renewal. 9

In times of insecurity, ties of friendship and kinship surmounted ideological differences among the elite. They were important in fostering alliances and in setting boundaries as a response to the crisis. At the European level, the main reference points for a decaying elite were Catholic counter-revolutionaries such as the early Félicité De Lamennais, Joseph De Maistre, Louis De Bonald, François-René De Chateaubriand

9 M. Broers, 'The Restoration in Piedmont-Sardinia, $1814^{-184} 8^{\prime}$, in D. Laven and L. Riall (eds), Napoleon's legacy: problems of government in Restoration Europe, Oxford 2000, 151-66; The politics of religion in Napoleonic Italy: the war against God, I80I-I8I4, London 2002; and 'Ideological change and national frontiers: from the fall of Napoleon's empire to the Savoyard Restoration: Subalpine Italy $1814^{-1821}$, in M. Broers, A. A. Caiani and S. Bann (eds), A history of the European Restorations: culture, society and religion, London 2020, 168-76; M. Meriggi, 'State and society in postNapoleonic Italy', in Laven and Riall, Napoleon's legacy, 49-64. 
and Karl Ludwig von Haller. ${ }^{10}$ They called to arms those across Europe who were still shaken by the colossal changes of the last decades and who, forced to co-exist in new sclerotised settings, looked with pessimism at the multiple revolutions that raged through the continent in 1820-1 and 1830 . They sided firmly with the papacy, which they perceived as a stronghold of the besieged old world. In France and the Italian states in particular, political, philosophical and scientific innovations tended to undermine the Church's primacy. ${ }^{11}$ Consequently, traditionalists' attitudes were limited to their old privileges and they offered only dogmatic responses to the matters of poverty and inequalities. Instead, while states adopted temporary paternalistic measures to ensure control of the masses, who paid the highest price during the cyclical economic crises, early instances of liberalism and socialism went to the core of the problems of the early industrial societies, addressing political economy. The mobilisation of Catholics in a wide and composite movement of thought and action was intended to demonstrate that Catholicism could provide solutions to modern problems. ${ }^{12}$

A younger generation of Catholic intellectuals, among them Alban Villeneuve-Bargemont and Frédéric Ozanam in France, and Antonio Rosmini, Vincenzo Gioberti, Cesare Taparelli, Luigi Taparell and Enrico Tazzoli in Italy, chose to translate Catholicism into a modern setting. Aiming to respond to the Restoration's contradictions, they proposed novel arguments on the organisation of society, contributing to the spread of seminal instances of social and liberal Catholicism and to the mobilisation of Catholics at a societal level. ${ }^{13}$

Trans-generational kinship with the old Ultramontanism was guaranteed by personal trust and by favouring the establishment of new confraternities and associations. Rosmini, for example, was closely linked to the Oratories of St Philip Neri in Padua, his alma mater (1816-19). Inspired by the gentle and cheerful spirituality of the Oratorians, he established in Rovereto the Society of Friends (1819), which proposed to propagandise

${ }^{10}$ B. Wilson, 'Counter-revolutionary thought', in G. Stedman Jones and G. Claeys (eds), The Cambridge history of nineteenth-century political thought, Cambridge 201 1, 12-38.

${ }^{11}$ A. M. C. Waterman, Political economy and Christian theology since the Enlightenment: essays in intellectual history, London 2004, 5 .

12 C. Clark, 'The new Catholicism and the European culture war', in C. Clark and W. Kaiser (eds), Culture wars: secular-Catholic conflict in nineteenth century Europe, Cambridge 2009, 13 .

13 Stefano Solari, 'Catholic perspectives on poverty and misery: from nineteenthcentury French Catholic social economists to the contribution of the Jesuits', Papers in Political Economy lix (2010), 185-203, and 'The dawn of the third way: the impact of neo-Thomistic thought on economic policy', in P. Bini and G. Tusset (eds), Theory and practice of economic policy: tradition and change, Milan 2008, 194-5; Waterman, Political economy, 129; D. Antiseri, Il liberalismo cattolico italiano dal Risorgimento ai nostri giorni, Soveria Mannelli 2010. 
a new Catholic pedagogy in a spirit of liberal communion among its members in Padua, Verona and Udine. In Turin (1821), he joined Catholic Friendship (Amicizia cattolica), a vast network of counter-revolutionary aristocrats, clergymen and bourgeois who, under the influence of De Maistre and Cesare Taparelli, promoted a revival of Catholicism among the masses. ${ }^{14}$ In Milan, between 1826 and 1828 , he developed a long-time friendship with Count Giacomo Mellerio, an influential member of various Ultramontanist charitable associations, and with the writer Alessandro Manzoni, who was deeply influenced by his thought. ${ }^{15}$

The relationship between politics and religion during the Restoration was pivotal in shaping the mindsets of this generation and in re-establishing Roman Catholic networks at a transnational level. Pervasive state control and censorship, which applied to the clergy and to the religious movements, were a daily threat to Catholicism. Most often, censorship intervened to truncate the most radical ideas, by confiscating epistolary exchanges, which were vital in maintaining trans-border contacts, and by refusing to grant an imprimatur to publications. The Austrian Empire implemented such censorship in Lombardy-Venetia, and the Savoy dynasty in Piedmont. ${ }^{16}$ Rosmini witnessed and experienced this. At the University of Padua, the curricula had to be approved by the Austrian authorities. During the 1820 sosmini's writings, and those of members of his networks, were censored multiple times in Milan, Turin and Padua. In 1828 Piedmont shut down Catholic Friendship, accused by Austria and Russia of plotting to restore the Jesuits, by then an illegal organisation. ${ }^{17}$

Personal networks supported Catholic activism. Drawing from the teachings of the Oratorians, and encouraged by his friend Maddalena di Canossa, founder of the Daughters of Charity in Verona (1808), and by the young missionary Giovanni Battista Loevenbruck, Rosmini established a new religious community, the Institute of Charity. The Institute was one of 207 Catholic religious institutions established in the first decades of the

${ }^{14}$ F. Traniello, Cattolicesimo conciliarista: religione e cultura nella tradizione rosminiana lombardo-piemontese (I825-I87o), Milan 1970, 23-4.

${ }^{15}$ P. Lorenzetti, 'Catene d'oro' e libertas ecclesiae: $i$ cattolici nel primo Risorgimento milanese, Milan 1992, 57-8; P. Floriani, 'Manzoni, Alessandro', in Dizionario biografico degli Italiani, lxix, Turin 2007, <http://www.treccani.it/enciclopedia/alessandro-manzoni_ $\%$ 28Dizionario-Biografico $\% 29 />$.

${ }^{16}$ J. A. Davis, 'Italy', in R. J. Goldstein (ed.), The war for the public mind: political censorship in nineteenth-century Europe, London 2000, 81-1 24; D. M. Bruni (ed.), Potere e circolazione delle idee: stampa, accademie e censura nel Risorgimento italiano, Milan 2007.

${ }^{17}$ G. Solari, Rosmini inedito: la formazione del pensiero politico, Turin 1938, 113; G. Lorizio, Eschaton e storia nel pensiero di Antonio Rosmini: genesi e analisi della Teodicea in prospettiva teologica, Brescia 1988, 106; F. de Giorgi, 'Il problema della riforma del clero e l'origine delle «Cinque piaghe»', in M. Marcocchi and F. de Giorgi (eds), Il 'gran disegno' di Rosmini: origine, fortuna e profezia delle «Cinque piaghe della Santa Chiesa», Milan 1999, 55-94. 
nineteenth century with the aim of reviving the Christian message of charity and benevolence. Its essence is about spiritual communion, working towards sanctity, rather than beneficence. ${ }^{18}$

As with all other orders, the Institute suffered restrictions in some states and was encouraged in others. The first house, opened in Mount Calvario in Savoy-Piedmont, was followed in 1831 by a new house in Trento and an oratory in Rovereto. While the Savoy authorities did not see Rosmini as a threat, the Austrian authorities closed down the houses at Trento and Rovereto within a few years. In Great Britain, however, the Institute was not troubled by the authorities. The missionary Luigi Gentili established a Rosminian house in Grâce Dieu in 1835, invited by the convert Ambrose March Philips de Lisle, and, in 1839, he moved to Loughborough, under the leadership of the Rosminian Giovanni Battista Pagani. ${ }^{19}$ With the support of local clergy, Rosmini's missionaries helped to spread Catholicism in England and Ireland, devoting themselves to supporting converted Anglicans; they succeeded in becoming part of the 'second spring of Catholicism' in England. ${ }^{20}$

Pope Gregory XVI approved the Constitutions of the Institute in 1839, one year before the Jesuits issued harsh polemics against Rosmini, accusing him of being sacrilegious. In this delicate situation the pope imposed silence on both the Jesuits and Rosmini. During his pontificate, Gregory had refused any movements towards reform, condemning Modernism, even though he accepted, pragmatically, the political changes that offered opportunities to Catholics in the United Kingdom, France and Belgium. ${ }^{21}$ After 1840 a nationalist ideology divided old Catholic alliances with regard to the role of the Church and the papacy within a unified Italy. Thinkers like Taparelli and Gioberti wished to see the pope as a leader or moral leader of a united Italy. Rosmini would have preferred the separation of Church and State, but he did not admit to that at that time. ${ }^{22}$

${ }^{18}$ De Giorgi, Il problema, 55-94; A. Nora, Charitas Christi urget nos: il carisma e la spiritualità cottolenghiana: aspetti ecclesiologici, Rome 2008, 187-8.

19 G. Monsagrati, 'Gentili, Luigi', Dizionario biografico degli Italiani, liii, Turin 200o, <http://www.treccani.it/enciclopedia/luigi-gentili_(Dizionario-Biografico)/>; G. Picenardi, 'Antonio Rosmini e la cura pastorale della Parrocchia', Rovereto 2010 , <https://www.rosmini.it/Resource/Rovereto/Rosmini\% 20cura\% 2opastorale\% 20st.pdf , accessed 2 Jan. 2020; P. Marangon, 'Pagani, Giovanni Battista', Dizionario biografico degli Italiani, lxxx, Turin 2014, <http://www.treccani.it/enciclopedia/giovanni-battistapagani_\%28Dizionario-Biografico\%29/>.

${ }_{20}^{\circ}$ C. Leetham, Luigi Gentili: a sower for the Second Spring, London 1965 .

${ }^{21}$ C. Barr, Ireland's Empire: the Roman Catholic Church in the English-speaking world, I 829-I9I4, Cambridge 2020, 16.

${ }^{22}$ F. Traniello, 'Le origini del cattolicesimo liberale', in F. Traniello (ed.), Da Gioberti a Moro: percorsi di una cultura politica, Milan 1990, 1 1-24: J. D. Durand, 'L'Italie entre renoveau et question nationale $\left(183^{0}-1849\right)$ ', in J. Gadille and J.-M. Mayeur (eds), Histoire du Christianisme, xi, Paris 1995, 270-3; L. Malusa, Antonio Rosmini per l'unità 
The hopes of Catholics for church reform, and of some of the Italian nationalists for national unification, came to the fore during the pontificate of Pius IX, which began in 1846 . Under Pius Ix, the Church became at the same time more Italian and more global: at the same time an Italian sovereign and the pastor of the universal Catholic Church. ${ }^{23}$ In the spring of 1847, Pius mobilised the Church globally, fundraising for the Irish. Rosmini's own fundraising, operating within this cultural, political and religious context, had already been underway for some months.

\section{Motivation: social justice between charity and beneficence}

Rosmini's thought is enlightening on why he decided to put such effort into organising charitable fundraising for the Irish. Rosmini treated political economy as an instrument for achieving public good in respect of the rights of the individuals. In the 1820 , from the counter-revolutionary authors, he adopted a pessimist vision of the post-1 789 constitutions: these do not distinguish between natural rights and social rights. Following De Maistre, he considered the constitutions dangerous abstractions, descendants of rationalism, which legitimated the simplistic and dangerous ideas of utilitarianism, economism, hedonism and materialism. ${ }^{24}$ In particular, he criticised the fact that private property was not considered one of the natural rights of the individual. Post-revolutionary rules allowed private property to be expropriated and seized, or gradually diminished by means of unfair taxes, for the public good. ${ }^{25}$ For Rosmini, private property was a sphere at the core of which lay the individual. It was a natural right of the individual. ${ }^{26}$ Following Haller, Rosmini believed that in ancient times the autonomous organisation of individuals into corporations, under the rule of a king inspired by Christian principles, was somehow a just system or at least, following De Maistre, a tradition to draw from in his times. ${ }^{27}$ In the next decade, reading Alexis de

d'Italia: tra aspirazione nazionale e fede cristiana, Milan 2011, 6o-1; G. Martina, Pio IX (I846-I85o), Rome 1974, 69-80.

23 C. O'Carroll, 'Pius Ix: pastor and prince', in J. Corkery and T. Worcester (eds), The papacy since 1500: from Italian prince to universal pastor, Cambridge 2010, 125-42; C. Duggan, La forza del destino: storia d'Italia dal I796 a oggi, Bari $2015,166$.

${ }^{24}$ F. Traniello, 'Letture rosminiane della Rivoluzione francese', and M. D'Addio, 'Il concetto di filosofia politica in Antonio Rosmini', in G. Campanini and F. Traniello (eds), Filosofia e politica: Rosmini e la cultura della Restaurazione, Trento 1993, 154, 15976; Pietro Piovani, La teodicea sociale di Rosmini, Padua 1957, $15^{-1} 7$.

${ }_{25}$ Luigi Bulferetti, Antonio Rosmini nella Restaurazione, Florence 1942, 65-6, 75-8o.

26 Alberto Mingardi, 'A sphere around the person: Antonio Rosmini on property', Journal of Markets and Morality vii (2004), 63-97.

${ }^{27}$ Bulferetti, Antonio Rosmini, $65^{-6,} 75^{-80}$. 
Tocqueville confirmed his hypothesis that democracy may become the tyranny of the majority and that it undermines individual freedom. ${ }^{28}$ As he would write in his constitutional projects, not published until 1848 , modern constitutions contained the seeds of communism and despotism. ${ }^{29}$

In the 183 os he accepted the challenge of the modern world's politics and economics. In his Philosophy of politics (1837-9), he attributed primary importance to individuals for the just managing of politics and economy. He showed that politics and economy are governed by morality. From there, he derived the importance of individuals and their Christian education and morals. Individuals are the main guarantors of social justice, a concept that Rosmini had conceived in 1839 and to which he referred often, although only vaguely. $3^{\circ}$ In Society and its purpose (the second volume of Philosophy of politics, published in 1839), Rosmini pointed out that "public good must be sought in the private citizens; social justice in the individual'.${ }^{11}$ In light of his views on economy, which supported liberal principles, social justice appeared as a product of individual responsibility. On the one hand, Rosmini followed Chateaubriand and Haller's theses on fair taxation, the certainty of private property and the freedom of trade. ${ }^{32}$ On the other hand, following de Sismondi, Rosmini invoked moral principles in his criticism of the laissez-faire in economy and the reduction of politics to the production of material goods. 33 Like de Sismondi, he was not nostalgic about medieval corporations but, contrary to de Sismondi, he considered the Saint-Simonian assumption of the universal possibility of happiness to be a false hope. Consequently, he opposed those political programmes that advocated universal rights and promoted the equality of individuals. 34 Taking the example of the post-1 $8_{34}$ English poor laws, he considered universal welfare to be a consequence of the modern confusion between justice and beneficence. He considered it unfair that the individual was forced by the state to support others economically. He refused to make individuals disappear within the category of proletariat as de Sismondi did, since the generic category

${ }_{28}$ A. Körner, America in Italy: the United States in the political thought and imagination of the Risorgimento, I763-I865, Princeton-Oxford 2017, 106.

29 A. Rosmini, The constitution under social justice, trans. A. Mingardi, Lanham 2007, 121 , and Il comunismo ed il socialismo, Genoa 1849.

$3^{\circ}$ Robert P. Kraynak, "The origins of "social justice" in the natural law philosophy of Antonio Rosmini', Review of Politics $\operatorname{lxxx}$ (2018), 3-29. Taparelli used the concept in 1843. See T. P. Burke, The concept of justice: is social justice just?, London 201 1, 31-3.

$3^{1}$ A. Rosmini, 'Society and its purpose', in his Philosophy of politics, ed. A. Belsito, trans. D. Cleary and T. Watson, Durham, NC 2010, 127.

$3^{2}$ Bulferetti, Antonio Rosmini, 53, 135.

33 C. Hoevel, The economy of recognition: person, market and society in Antonio Rosmini, Dordrecht 2013. See also Piovani, La teodicea, 105.

34 Piovani, La teodicea, 77-9, 100-5. 
of class ('the poorest') negated the individual and promoted the unjustifiable pauperism of universal welfare. 35

In the 184 os Rosmini formulated his proposal for a political economy that could preserve individual freedom and natural rights, including private property. In his Philosophy of right $\left(184^{1-5}\right)$, he defined four coexisting ideal types of society: theocratic (the Catholic Church), domestic (the signoria), political (the state) and civil. He defined civil society as a community of citizens who co-operate for the common good. In Rosmini's words, civil society is 'the union of a certain number of fathers [padri]'. $3^{6}$ Only these fathers who were rich senior men who could afford to support other members of the family and society would have the right to hold positions in government. Poor people and women could not possess active rights in civil society because they could not afford to contribute to society. Therefore, ownership of private property differentiated the role of the individual in society. In Rosmini's view, government should be under the control of a universally elected 'political tribunal'.37 In this way, rights and properties would be equally represented. Such a dual system, for Rosmini, would be less unjust than others. However, he was conscious that even this system could at most guarantee the common good by the fair representations of rights and properties - but not social justice, since no system could.

Rosmini thought that only morality injected both justice into political economic systems and social justice among individuals. In economy, morality helps the individual to distinguish between what is essential and what is not. $3^{8}$ In connection with entitlement to aid, Rosmini distinguished between aid in times of emergency and in ordinary times, each of which pertained to two spheres: to the juridical and the moral respectively. In modern Italian, carità (charity) referred to the Greek virtue of $\dot{\alpha} \gamma \dot{\alpha} \pi \eta \eta$, the love of God, while beneficenza (beneficence) referred to charitable activities, either individual or collective, the latter being exercised via 'opere di beneficenza' (charitable works). In ordinary circumstances direct assistance to the poor was a moral obligation, a matter of beneficence. 39 As Rosmini wrote, donations were acts of benevolence and liberality, $4^{\circ}$ and 'the distinctive characteristic of charity [beneficenza] is its spontaneity'. ${ }^{4^{1}}$ For this reason he thought that the state should not tax its citizens in order to provide aid.

35 A. Rosmini, Filosofia della politica, Naples 1842,234 n.1.

${ }^{6}{ }^{6}$ Idem, 'Rights in civil society', in his The philosophy of right, vi, ed. A. Belsito, trans. D. Cleary and T. Watson, Durham, NC 1996, 25.

37 L. M. Gadaleta, 'La naturale costituzione della società civile in Edizione critica', Stresa 2017, <http://www.rosmini.it/Resource/CentroStudi/Simposi/2017/11\% 2oGadaleta\% 2orelazione.pdf $>$, accessed 20 June 2018.

$3^{8}$ Piovani, La teodicea, 77-9. $\quad 39$ Hoevel, The economy, $201 . \quad 4^{\circ}$ Ibid.

$4^{1}$ 'Il carattere proprio della beneficenza ... è la spontaneità': A. Rosmini, 'La costituente del Regno dell'Alta Italia', in A. Rosmini, Opere edite e inedite, xxiv, Milan $195^{2}$, 266. Unless otherwise indicated all translations are by this author. 
Here come into play the roles of the individual and the Church in guaranteeing social justice. In the Constitutions of the Institute of Charity (1828), Rosmini had stressed that Christians must embrace good feelings and natural instincts, among which is the compassion raised when seeing the sufferings of others; charity sanctifies such feelings. ${ }^{42}$ In ordinary situations, it is the individual's responsibility to choose what is right and what is wrong. Just exercise in economic freedom demands morality. In certain cases, individuals must sacrifice some of their natural rights for the sake of peace and mutual respect. 43 Therefore, for Rosmini as well as for Manzoni, moral economy lay between the science of economy and the moral improvement proper of the good Christian. The good was in individual Christians and in their morals. In this sense, Rosmini endorsed 'liberalism': the act of donating did not pertain only to the sphere of beneficence, but also to taking responsibility for the good of others. 44 In cases of existential necessity, aid was, for Rosmini, a mandatory act of justice to be implemented by governments and by what the individual 'has on hand'.45 Rosmini did not specify the cases of extreme necessity that transformed charity into an act of social justice, $4^{6}$ but the Great Irish Famine, evidently, was one of them.

Since the 184 os several exponents of the Italian Risorgimento had expressed opinions on Irish politics and economy, despite the irrelevance of Ireland to Italian politics. 47 Some protagonists of the Risorgimento considered the Union with Great Britain as just, because they saw it as a means to civilise Ireland (Camillo Benso, Count Cavour) or to save it through agricultural innovations (Carlo Cattaneo), or simply because they did not consider the Irish as a nation (Giuseppe Mazzini). $4^{8}$ Rosmini, like Vincenzo Gioberti, Cesare Balbo and Massimo D'Azeglio, thought otherwise. These Catholics were admirers of Daniel O'Connell, the proponent of Catholic Emancipation and leader of the Repeal movement, for his

$4^{2}$ Idem, Costituzioni dell'Istituto della Carità, Rome 1996, 170.

43 Piovani, La teodicea, 332; Hoevel, The economy, 11 7-18.

44 See the description of Federigo Borromeo as a 'liberal' man in A. Manzoni, I promessi sposi, Milan 1985 , 395-7. For this interpretation see F. Traniello, 'Le «Cinque piaghe» e le utopie del '48', in Marcocchi and De Giorgi, Il 'gran disegno' di Rosmini, $125^{-47}, 193$.

45 '[Il diritto che ha l'uomo di servirsi di] ciò che gli viene alle mani nel caso di estrema necessità': Rosmini, 'La costituente', 266.

$4^{6}$ Hoevel, The economy, 200-1.

47 C. Barr, M. Finelli and A. O'Connor (eds), Nation/nazione: Irish nationalism and the Italian Risorgimento, Dublin 2013; N. Carter (ed.), Britain, Ireland and the Italian Risorgimento, Basingstoke 2015 .

$4^{8}$ C. B. Cavour, Considérations sur l'état actuel de l'Irlande et sur son avenir, Geneva 1844 ; C. Cattaneo, 'Rapporti', Giornale dell' Istituto lombardo e Biblioteca italiana xvi (1847), 1 72 2238; M. Finelli, 'Mazzini e il mondo anglosassone: nuovi spunti di riflessione', in F. Guida (ed.), Dalla giovine Europa alla Grande Europa, Rome 2007, 90-9. 
moderation and tolerance in leading the Irish back to Catholicism against what they defined as British despotism. 49

Rosmini's first reference to Ireland dates back to the early 1830 . The campaign for Catholic emancipation had accomplished its most significant success with the passing of the Roman Catholic Relief Act (1829), which had allowed O'Connell to take his seat in the British parliament, to which he had been elected the previous year. The feared royal veto on the appointment of the Catholic bishops had not been introduced, thanks to the popular mobilisation achieved by O'Connell. In Of the five wounds of the holy Church, written between 1832 and 1833 (but not published until 1846), Rosmini praised the British and Irish state for not interfering in the election of bishops. The state's respectful treatment of Catholics in Ireland demonstrated that governments could, by means of just legislation, contribute to preventing revolutions and uprisings which Rosmini did not condone. $5^{\circ}$ O'Connell's achievements were due to his non-violent and legal methods, which convinced many Catholic intellectuals in Italy and Ireland to enter the political debate. ${ }^{51}$ Rosmini was one of them. In 1837 he wrote to Lamennais that O'Connell 'does not encourage those people [the Irish] to rebel: rather, he keeps them in due submission. His plan is to make use of legal means for the benefit of his country'. $5^{2}$

In other matters Rosmini considered Great Britain and Ireland less worthy of praise. In his Philosophy of right (1845), in order to demonstrate that a state organisation deprived of justice 'is the source of innumerable other evils' even in nations whose 'sense of morality and justice cannot be denied', Rosmini used the example of England, where landowners who could access parliament passed laws in their own favour. Referring to O'Connell's memoires, he indicated that Ireland's state organisation

49 V. Gioberti, Del primato morale e civile degli italiani, ii, Capolago 1846, 399; C. Balbo, Delle speranze d'Italia, Capolago 1844, 104, 157, 232-3; M. D'Azeglio, Degli ultimi casi di Romagna, [Florence] 1846, 46, 212.

$5^{\circ}$ A. Rosmini, Of the five wounds of the holy Church, London 1848, 296. Rosmini published this anonymously in 1846 , after the election of Pius IX, who incarnated his hopes for the reform of the Church. See Traniello, Le "Cinque piaghe», 126.

$5^{1}$ Barr, Ireland's empire, 16-17, and "'An Italian of the Vatical type": Roman formation of Cardinal Paul Cullen, archbishop of Dublin', Studi Irlandesi: A Journal of Irish Studies vi (2016), 27-47.

$5^{2}$ Rosmini to Hugues-Félicité de Lamennais, 22 Mar. 1837, in A. Rosmini, A selection from the ascetical letters of Antonio Rosmini, III: $1837-1840$, trans. J. Morris, Loughborough 1996, 15 . See also C. Leetham, Rosmini, priest, philosopher and patriot, London 1957, 216 , and A. Giordano, Rosmini e Lamennais: fede e politica, Stresa 1989, 69. Gioacchino Ventura praised O'Connell for having kept the Irish in a state of 'passive resistance' and 'active obedience': Elogio funebre di Daniello O'Connell, Rome 1847, 42-5. 
was similarly deprived of justice. ${ }^{53}$ Despite the successes of Catholic emancipation in Ireland, the obligation to pay tithes to the Anglican Church had remained, leading to a series of episodes of civil disobedience and sporadic violence.

Rosmini thought that equity in taxation was a matter of right. $54 \mathrm{He}$ suggested that taxes should be calculated according to anticipated government expenses, and that any excess was abuse and exploitation. In this connection he added a note distinguishing between the gifts to kings given by their subjects in ancient times and the taxes to be paid to the authorities in modern times. While the gifts were fixed irrespective of the needs of society, the taxes varied every year according to perceived requirements. The tithes that the Irish were obliged to pay, he explained, were ' $a$ patent and immense injustice', since they were collected as a governmental tax while they were an offer to the theocratic society that obliged the whole population to fund the Anglican Church even though most people in Ireland were Catholic. 55 However, referring to the 'great human dignity' of the Irish and their 'uniformity of thought in social justice', he prophesied that social justice would one day prevail. $5^{6}$

In December 1846 , the worst phase of the Great Famine began. In such a crisis Rosmini was convinced of the need to provide charitable help to the distant Catholics of Ireland. He was among the readers of the official newspaper of the Savoy-Piedmont, the Gazzetta Piemontese. Day by day, from midDecember 1846 , the Gazetta reported increasingly horrifying news on the famine. On 29 December it reported that the English government was powerless in the face of the catastrophe. 57 This, most probably, was what motivated Rosmini to put his philosophy into practice, organising fundraising for the Irish. On 31 December 1846 Rosmini wrote to an associate in England, the rector of Ratcliffe College, Father Giovanni Battista Pagani, that the Institute of Charity ought to show the charity that God inspired. The letter exhorted Pagani to initiate unusual and extraordinary activities and to do everything that was possible to help the Irish. $5^{8}$

53 A. Rosmini, 'Universal social right', in Rosmini, Philosophy of right, iii, Durham, NC 1995, 82 n. $5^{8}$, and Filosofia del diritto, ii (Opere, xxiv), $5^{8}$ n. 1; D. O'Connell, Memoria storica sopra l'Irlanda e gli irlandesi, Turin 1843.

54 Bulferetti, Antonio Rosmini, 53 n. 1.

55 A. Rosmini, 'Rights in civil society', in Rosmini, Philosophy of right, vi. $45^{6-7}$.

$5^{6}$ Idem, 'Rights', 225.

57 Gazzetta Piemontese, 29 Dec. 1846 , 3. See also 16 Dec. 1846, 3; 21 Dec. 1846 , 2; 22 Dec. 1846 , 1 ; 23 Dec. 1846 , 2; 24 Dec. 1846 , 1; 26 Dec. 1846 , 2.

$5^{8}$ Rosmini to Giovanni Pagani, 31 Dec. 1846 , in A. Rosmini, Opere edite e inedite: epistolario, ii, Turin 1857 , letter 454 at pp. $273-4$. 


\section{Appealing for Ireland in Restoration Savoy-Piedmont}

Rosmini himself undertook many of the efforts that he had requested of Pagani. However, he was not alone in thinking that a charitable collection was necessary. The same idea was proposed to him by Giuseppe Andrea Sciolla, professor of theology at the University of Turin, a fervid follower of Rosmini and lay member of the Institute of Charity.59 In early January 1847 Sciolla told Rosmini about his intention to donate to the poorest in Ireland. Rosmini invited him to send a bill of exchange through a broker in Milan in favour of Pagani. ${ }^{60}$

Sciolla's involvement also made advertising the initiative possible. ${ }^{61}$ Rosmini believed that a public appeal was the most appropriate way of starting a fundraising drive, since the Savoy-Piedmont audience knew from the newspapers of the extreme suffering in Ireland. However, freedom of the press was granted only in the turbulent year of 1848. The Gazzetta Piemontese was the only official news organ of the Savoy-Piedmont, and was under the direct supervision of the state secretary. ${ }^{62}$ In the Italian states, several collections for Ireland were partially or totally prevented by the authorities, who held a monopoly on information. ${ }^{63}$ This also prevented the wide distribution of the Praedecessores Nostros, the papal encyclical published in mid-April which invited bishops to fundraise for Ireland and send the offers to Propaganda Fide in Rome. In the Savoy-Piedmont, the Praedecessores Nostros was reduced to a five-line 'letter from Rome' on 1 May. ${ }_{4} 4$

In order to succeed with an appeal under such conditions, Rosmini had to bring into action his friends and brothers of the Institute of Charity who were close to the centre of state power. In mid-January, Sciolla asked Count Clemente Solaro della Margarita, the fervently Catholic foreign minister of the kingdom who was in charge of publishing newspapers, to allow the

59 D. Mariani, Superiori e vescovi rosminiani, Stresa 2003, 127-35; M. Tringali, 'Antonio Rosmini e il Marchese Gustavo Benso di Cavour', Quaderni di Teoria (2/ 2007); A. Rosmini, Constitutions of the Society of Charity, Durham, NC 1992, 129-32, and Introduzione alla filosofia, Casale Monferrato $185^{\circ}, 124$.

6o Rosmini to Guiseppe Sciolla, 12 Jan. 1847 , in his Epistolario completo, xiii, Casale 1894 , letter 8159 at p. 31 6; Sciolla to Pagani, 18 Jan. 1847 , ASIC, AG 24, 1847 , fo. 91.

61 Carlo Gilardi to Pagani, 12 Jan. 1847 , ASIC, A1, XXII, fo. $591 \mathrm{r}-\mathrm{v}$.

62 R. Buoso, 'Le gazzette', in G. Ricuperati (ed.), Storia di Torino: dalla città razionale alla crisi dello stato d'antico regime (I 730-I 798), Turin 2002, 949-62 at p. 960.

${ }^{6}$ See Lettera dalla Segreteria del Regio Diritto al Vescovo Barzellotti, 2 June 1847 , Archivio Diocesano di Pitigliano, lettere vescovili, i/ 5 ; Lettera dal Governo di Venezia al Vescovo di Treviso, 12 Aug. 1847, Archivio Storico Diocesano di Treviso, fondo Governo Diocesi, b. 31 , fasc. 2.

64 'Una lettera di Roma': 'Italia', Gazzetta Piemontese, 1 May 1847, 3. 
appeal to be printed in the Gazzetta Piemontese. ${ }^{6} 5$ This appeal was signed by Francesco Puecher, the provincial of the Institute of Charity in Piedmont. In a short and minimalistic text, the Institute declared itself ready to receive and forward any sums that compassionate persons would like to send to Ireland. ${ }^{66}$ Della Margarita, who thought that the tithes paid by the Irish were 'a solemn injustice', ${ }^{67}$ was not allowed to permit the publication of 'articles aimed at heating up the spirits or being offensive to any foreign power' ${ }^{68}$ We do not know the exact reason why he granted permission to publish, but he did so immediately. ${ }^{69} \mathrm{He}$ even granted a second publishing permit in mid-February. $7^{\circ}$

\section{Rosmini's networks in Savoy-Piedmont and Lombardy-Venetia}

Since mid-January 1847 Paul Cullen, rector of the Pontifical Irish College in Rome, had been collecting alms for Ireland. Rosmini, invited by Cullen to coordinate their respective collection, replied that he had already started fundraising, that a committee in Turin had been established, and that he would try to advance the cause of Ireland when he visited Milan. ${ }^{7}$ Rosmini's efforts to mobilise his wide networks in Savoy-Piedmont and Lombardy-Venetia and to collect alms was successful. The second appeal published by Puecher in the Gazzetta Piemonteseshows that Gustavo Benso, marquis of Cavour - a fervent admirer of Rosmini who assisted in the administration of the Institute's patrimony $7^{2}$ - provided direct help in collecting funds in Turin. He also had the help of another member of the nobility, the

${ }_{5}$ Rosmini to Sciolla, 13 Jan. 1847 , Epistolario completo, xiii, letter 8160 at p. 316 ; 'Solaro Della Margarita, Clemente', in L'Unificazione, Turin 2011, <http://www.treccani.it/enciclopedia/solaro-della-margarita-clemente_\% $28 \mathrm{~L} \%{ }_{27}$ Unificazione \% 29/>.

${ }^{66}$ Francesco Puecher, 'Appello per gli irlandesi affamati', Gazzetta Piemontese, 19Jan. 1847,4 .

${ }^{7} 7$ 'Una solenne ingiustizia': C. S. Della Margarita, L'uomo di Stato indirizzato al governo della cosa pubblica, Turin 1864, 349 .

68 'articoli che assecondassero le passioni e fossero ad alcuna Potenza ingiuriosi': idem, Memorandum storico politico:dal 7 febbraio I 835 al 9 ottobre I 847 , Turin 1851, 418 .

69 Sciolla to Pagani, 18 Jan. 1847 , ASIC, AG 24, 1847 , fo. 91.

$7^{\circ}$ Francesco Puecher, 'Avviso', Gazzetta Piemontese, 19 Feb. $1847,4$.

${ }^{71}$ Rosmini to Cullen, 18 Feb. 1847 , Epistolario completo, $1844^{-46}$, xix, Casale Monferrato 1887 , letter $5^{814}$ at pp. $747-8$; Rosmini to Pagani, 31 Dec. 1846 , Cullen papers, NC, $4 / 1846 / 27$.

$7^{2}$ F. Traniello, 'Benso, Gustavo, marchese di Cavour', Dizionario biografico degli Italiani, xxiii, Turin 1979, <http://www.treccani.it/enciclopedia/gustavo-benso-marchese-di-cavour_(Dizionario-Biografico)>; A. Valle, 'Rosmini e i Fratelli Cavour', in U. Muratore (ed.), Rosmini e la cultura del Risorgimento, attualità di un pensiero storico-politico, Stresa 1997, 127-48; Tringali, 'Antonio Rosmini', 32n; G. Picenardi, 'Antonio Rosmini e il denaro: istruzioni per l'uso', in F. Ghia and P. Marangon (eds), Rosmini e l'economia, Trento $2015,89-115$ at p. 100. 
marquis de Roussy. Direct help in Turin was also provided by other clerics: along with Puecher's assistant, Lorenzo Gastaldi, the royal chaplain Emmanuele Faraut was involved. Puecher's second appeal stressed that many persons, especially from Turin, had donated, but also that the work would be easier if more would follow the example given by the nobles and clerics who had offered to collect the alms.73 In Turin, Rosmini could count on a wide network of close friends and loyal adherents. Among these were Sciolla's university colleagues Pietro Antonio Conte, lecturer in theoretical philosophy, and Giovanni Michele Tarditi, lecturer in natural theology.74 Others included a former university colleague of Rosmini, Pier Alessandro Paravia, at that time chair of the Italian oratory at Turin University, and illustrious persons such as Paolo Barone and Giuseppe Buroni.75

In Milan, Rosmini could count on his close relationships with many local nobles, intellectuals and clerics. At the beginning of February 1847 he announced to Manzoni that he would visit Milan for some days at the end of February and the beginning of March. $7^{6}$ During his visit, he met Mellerio, the main financer of the Institute of Charity.77 Mellerio's support for the Institute and for Catholicism continued until his death in December 1847. In his testament, written in October, he earmarked copious sums to Rosmini, the English converts to Catholicism John Henry Newman and George Spencer, and William Bernard Ullathorne, future bishop of Birmingham and supporter of the Rosminians. $7^{8}$ Mellerio immediately gave his financial support to helping the Irish Catholics and spread the word among his network in Milan.79

Other influential Rosminians in Milan may have been involved in fundraising. Almost all the institutions for assistance and charity established in

73 Puecher, 'Avviso'.

74 Rosmini, Introduzione alla filosofia, 124 . See also V. Gioberti, 'Degli errori filosofici di Antonio Rosmini', in V. Gioberti, Opere, ii, Naples 1845, p. xiii; Picenardi, Antonio Rosmini e il denaro, 1 oo.

75 Rosmini, Introduzione alla filosofia, 124 . See also D. Mariani, 'Monsignor Lorenzo Gastaldi (1815-1883)', Stresa 2009, <http://www.rosmini.it/Resource/2009\% 20Mons\% 20Gastaldi.pdf $>$, accessed 16 Feb. 2018.

${ }^{76}$ Rosmini to Alessandro Manzoni, 4 Feb. 1847 , in A. Manzoni, Epistolario: carteggio A. Manzoni-A. Rosmini, Rome 2008, letter 36 , <http://ww2.bibliotecaitaliana.it/xtf/ view?docId=bibitooo897/bibitooo897.xml\&chunk.id=d7 1 e2269\&toc.depth=1\&toc.id= \&brand $=$ newlook $>$.

77 A. Arisi Rota, 'Mellerio, Giacomo', Dizionario biografico degli italiani, lxxix, Turin 2009, <http://www.treccani.it/enciclopedia/giacomo-mellerio_\% 28DizionarioBiografico $\% 29 />$.

$7^{8}$ 'Legati di culto e di pubblica e privata beneficenza estratti dal testamento di S. E. il Conte Giacomo Mellerio', Il Cattolico xxx (1/1848), 85-9o.

79 'English and foreign Catholic subscriptions', and 'English subscriptions for the relief of Irish distress', The Tablet, 6, 20 Mar. 1847; Alessandro Fioretti to Rosmini, 20 Feb. 1847 , ASIC, AG 51, 1847 , fo. 717 . 
the diocese of Milan between the 183 os and 189 os were founded by Rosminians or inspired by the teachings of Rosmini. His ideas had been popularised since 1841 in the pages of L'Amico Cattolico, thanks to the support of Father Alessandro Pestalozza, professor at the philosophy seminar of Monza. The Rosminians of Milan regularly preached on the virtues of charity and carried out relief activities for the poorest in the peripheries. ${ }^{80}$ Within this network, Rosmini maintained close relations with Fr Felice Pestalozza, Fr Nazaro Vitali, Ambrogio Vitali, Luigi Biraghi (founder, in 1836 , of the Sisters of Saint Marcellina, devoted to charitable initiatives) and Fr Giulio Ratti. ${ }^{81}$ It is therefore probable that they took part in the charitable fundraising and convinced others to do so.

This voluntary initiative was at the mercy of each financial transaction. Consequently, the donors and fundraisers implemented strategies to avoid dispersing the money in banks' commissions. Several hand-to-hand passages of money between the donors and their helpers, despite some delays and error-prone aggregation of sums destined to distinct causes, succeeded in preserving the sums for the entitled subjects. ${ }^{82}$ These practices continued through March and April. ${ }^{83}$

After the international distribution of the encyclical, Rosmini wrote to Cullen, declaring that he would send further offerings, although there is no evidence that he did so. ${ }^{8}$ Rosmini seems to have felt that the emergency had passed, as also witnessed by the drop in the amount of money collected. Charity, in Rosmini's interpretation of it, soon turned into beneficence again, implying a more discretionary approach to the problem of the Irish famine. Apart from the British government's premature announcement that the famine was over, ${ }^{85}$ the Institute had other priorities. On 27 December 1847 Sciolla sent to Rosmini another bill of

${ }^{80}$ B. Ferrari, 'Dalla rivoluzione francese alla morte dell'Arcivescovo Calabiana: l'età del Risorgimento', in A. Caprioli, A. Rimoldi and L. Vaccari (eds), Storia religiosa della Lombardia, IX: Diocesi di Milano, II, Brescia 1990, 676-7; L. Carotti, 'Pestalozza, Alessandro', Dizionario Biografico degli Italiani, lxxxii, Turin 2015 , <http://www.treccani. it/enciclopedia/alessandro-pestalozza_(Dizionario-Biografico) $/>$.

${ }^{81}$ Lorenzetti, 'Catene d'oro' e libertas ecclesiae, 301-2; F. de Giorgi, Cattolici ed educazione tra restaurazione e risorgimento: ordini religiosi, antigesuitismo e pedagogia nei processi di modernizzazione, Milan 1999, 41; I. Pederzani, I Dandolo: dall'Italia dei lumi al Risorgimento, Milan 2014, 262.

${ }^{82}$ Gilardi to Fioretti, 30, 26 Mar. 1847 , ASIC, AG 51, 1847, fos $718 \mathrm{r}-\mathrm{v}, 717 \mathrm{v}$.

83 Other offers were sent from the Veronese Barnabite Father Giovanni Piantoni, and from Rosmini's brother Giuseppe. See Rosmini to Pagani, 1o Mar. 1847; Rosmini to Luigi Moretti, 10 Apr. 1847; Rosmini to Pagani, 23 May 1847; and Rosmini to Paolo Orsi, 20 Apr. 1847 , in his Epistolario completo, X: $1847-1850$, Casale Monferrato 1 892, letter 5835

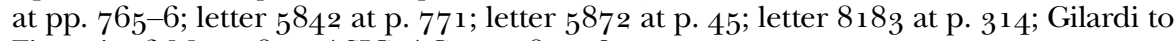
Fioretti, 26 Mar. 1847 , ASIC, AG 51, 1847 , fo. $717 \mathrm{v}$;

${ }^{8}$ Rosmini to Cullen, 6 May 1847 , Epistolario completo, x, letter $5^{8} 5^{6}$ at p. 16 .

85 Kinealy, Charity, 35 . 
exchange for Pagani so that he could distribute funds 'to the poor Catholics of his neighbourhood or of Ireland depending on what would be considered more appropriate'. ${ }^{86}$ A few days later Rosmini wrote to his brothers at Ratcliffe College that they could perhaps distribute Sciolla's funds among the poor in the vicinity. ${ }^{87}$ With the crisis perceived as over, the patriarchs of civil society could turn their efforts to their most pressing aims.

According to Rosmini, individuals were responsible for implementing social justice, since no political economic system is sufficient to guarantee it. In times of emergency, aid should be given by governments, if these are informed by principles of social justice. If the governments do not act, it is up to individuals to take responsibility. Following this philosophy, Rosmini and his network collected $£ 5^{10}, 7$ per cent of all funds raised by the Italian churches for the Irish poor in 1847.88 In 1848 Rosmini and a large part of his network took part in the revolutions that were shaking the Italian states. He was appointed as the Savoy-Piedmont plenipotentiary to the papal states. He published his projects for a constitution, in which he supported the unity of an independent Italy, and disclosed his authorship of Of the five wounds of the holy Church. With the failure of the revolutions in 1849 , proAustrian, conservative and Jesuit cardinals ensured that the Holy Office condemned some of his propositions. ${ }^{89}$ Absolved of such charges one year before his death in 1855 , some of his works were once again condemned in 1887 by the Holy Office and rediscovered only with the Second Vatican Council. Although Rosmini had been excluded from the range of precursors of social Catholicism, Leo xIII's encyclical Rerum Novarum (1891) in many respects echoes many of his precepts. The idea that charity is justice in situations of emergency is explicitly expressed. $9^{\circ}$

86 'a poveri cattolici de' suoi dintorni, o di Irlanda secondo che meglio si stimerà': correspondence: Sciolla to Rosmini (unpublished), 21 Dec. 1847, ASIC, XXII, 1847 , fos $1398 \mathrm{r}-\mathrm{v}, 1399^{\mathrm{r}-\mathrm{v} \text {. }}$

87 Rosmini to Pietro Bertetti, 26 Dec. 1847 , in Rosmini, Epistolario completo, x, letter 6051 at pp. $206-7$.

88 Francesco Zavatti, 'Appealing locally for transnational humanitarian aid: Italian bishops and the Great Irish Famine', Quellen und Forschungen aus italienischen Archiven und Bibliotheken ic (2019), 313-39.

89 Malusa, Antonio Rosmini, 6o-73; De Giorgi, Cattolici ed educazione, 301-3.

$9^{\circ}$ Stefano Solari, 'The contribution of neo-Thomistic thought to Roman Catholic social economy', American Review of Political Economy v (2007), 39-58 at p. 43 n. 13; V. B. Lewis, 'Catholic social teachings and common good', in G. V. Bradley and E. Christian Brugger (eds), Catholic social teachings, Cambridge 2019, 249; F. Forte, F. Felice and E. Beqiraj, 'Rerum Novarum and its principle on the just taxation of immovable properties', in H. A. Frambach, J. Backhaus and G. Chaloupek (eds), On the economic significance of the Catholic social doctrine: I 25 years of Rerum Novarum, Cham 2007, 135-66; Leo XIII, Rerum Novarum, 1891, proposition 22. 